\begin{tabular}{|l|l|l||}
\hline \multicolumn{2}{|c|}{ PublisherInfo } \\
\hline \hline PublisherName & $:$ & BioMed Central \\
\hline \hline PublisherLocation & $:$ & London \\
\hline \hline PublisherImprintName & $:$ & BioMed Central \\
\hline \hline
\end{tabular}

\title{
Bacteria rapidly develop resistance to new antibiotic
}

\begin{tabular}{||l|l|l||}
\hline \multicolumn{2}{|c|}{ ArticleInfo } \\
\hline \hline ArticleID & $:$ & 4059 \\
\hline \hline ArticleDOI & $:$ & $10.1186 /$ gb-spotlight-20010423-02 \\
\hline \hline ArticleCitationID & $:$ & spotlight-20010423-02 \\
\hline \hline ArticleSequenceNumber & $:$ & 130 \\
\hline \hline ArticleCategory & $:$ & Research news \\
\hline ArticleFirstPage & $:$ & 1 \\
\hline \hline ArticleLastPage & $:$ & 3 \\
\hline \hline & $:$ & RegistrationDate : 2001-04-23 \\
ArticleHistory & $:$ & OnlineDate \\
\hline \hline ArticleCopyright & $:$ & BioMed Central Ltd2001-04-23 \\
\hline \hline ArticleGrants & $:$ & \\
\hline \hline ArticleContext & $:$ & 130592211 \\
\hline \hline
\end{tabular}




\section{John K Borchardt}

Email: jkborchardt@aol.com

HOUSTON About 88,000 deaths annually are attributed to infections picked up during US hospital stays. In about 16,000 of them the bacteria are resistant to antibiotics. The spread of drug-resistant bacteria in hospitals has increased 300-400\% since 1995, according to Donald Low, chief of microbiology at New York's Mount Sinai Hospital.

For years the last line of defence against drug-resistant bacteria has been vancomycin. But bacteria already resistant to other antibiotics are becoming increasingly resistant to vancomycin. So physicians were encouraged when Pharmacia introduced Zyvox last year. The first new antibiotic in 25 years and known generically as linezolid, Zyvox is the first of a class of drugs called oxazolidinones. (The correct chemical name is actually oxazolidenediones.) Linezolid has an unusual mechanism of action. It binds to the $23 \mathrm{~S}$ ribosomal RNA of the $50 \mathrm{~S}$ subunit on the bacterial ribosome to prevent formation of an initiation complex in protein synthesis. By halting production of proteins vital to bacterial growth early in the life cycle, linezolid prevents multiplication of bacteria.

The US Food and Drug Administration has licensed linezolid to treat a group of illnesses including pneumonia and infections of the blood, abdomen and skin caused by methicillin-resistant Staphylococcus aureus(MRSA). Linezolid is the first new drug treatment in 40 years for MRSA, which infects 80,000 patients a year.

Oxazolidinones are effective against "virtually all these resistant bacteria causing so much trouble in hospitals throughout the world," observed Robert Moellering Jr, professor of medicine at Harvard Medical School and chairman of the department of medicine at Beth Israel Deaconess Medical Center. Completely synthetic drugs such as linezolid "have not been present in nature, thus one would not expect a reservoir of resistance," he says.

During linezolid clinical trials, a small number of cases of infectious diseases developed resistance to the drug but Pharmacia said it was confident that the likelihood of resistance would be low. In the lab, bacteria did not readily mutate to fight off linezolid. Therefore, Moellering thought "there's a good chance it will take longer for resistance to occur, but the bugs always seem to find a way."

Unfortunately, the bugs have found a way in much less time than thought possible, according to results of a limited study conducted by Robert Gonzales and co-workers from University of Illinois College of Medicine. The study involved five severely ill patients infected with vancomycin-resistant enterococcus (VRE). Three patients did not respond to extended linezolid treatment, despite their initially favourable response. "Resistance may emerge during linezolid therapy for vancomycin-resistant enterococci infection, especially during long courses, and may be associated with treatment failure," Gonzales said in the 14 April Lancet.

The authors reported the frequency of documented emergence of resistance to linezolid in VRE in their hospitals was one in 45 patients (2.2\%). They advise clinicians using linezolid for VRE infections to measure susceptibility of all isolates when beginning therapy. "Attention to proper dosing and prompt removal of infected devices, when feasible, could limit emergence of resistance," he suggests. 
One might expect physicians to be dismayed at Gonzales's findings but they seem to have made a measured response. "These cases are not unexpected," said Gary Noskin, Associate Professor of Medicine, Northwestern University Medical School. "The report of resistance reflects the special condition of these very few patients," he says.

\section{References}

1. US Food and Drug Administration, [http://www.fda.gov]

2. Harvard Medical School, [http://www.med.harvard.edu/]

3. Beth Israel Deaconess Medical Center, [http://www.bidmc.harvard.edu/]

4. Gonzales RD, Schreckenberger PC, Graham MB, Kelkar J, Den Besten K, Quinn JP: Infections due to vancomycin-resistance enterococcus faecium resistant to linezolid. Lancet 2001, 357:1179., [http://www.thelancet.com]

5. University of Illinois College of Medicine, [http://www.med.uiuc.edu/] 